(b) The green pyrochrome of the boric acid was unaltered (no soda

(c) The substance floated in the bead in bluish-white, fat-like, amorphous fragments like alumina or opaque silica as tabasheer, but-

(d) On continued heating, the fragments gradually disappeared, leaving bubbles, until in half an hour, with fresh boric acid, there was simply a transparent bead left; exactly the behaviour of minute fragments of diamond in boric acid.

Silica is absolutely, and alumina nearly, insoluble in boric acid before the blowpipe.

One conclusion, therefore, seems this: that a slow solution of charcoal in the water takes place, and that crystals of carbon are deposited upon the aluminium.

London. December, 1878

W. A. Ross

\section{Observations on the Microphone}

WITH regard to an explanation of the action of the microphone I observed a fact which, though it was already known from some anterior experiments with strong galvanic currents, lias not been remarked; as far as I know, with this instrument. On connecting the current from six Grove cells with the micro. phone (the telephone not being: in the circuit) composed of the three carbon rods, the vertical one assumes a vibratory motion between its supports, which canses a very audible sound, especially when placed on a sounding-board.

I think this experiment may serve as another illustration of the well-known fact, discovered by Ampère, of the repulsive action between the subsequent parts of a rectilinear current. Most of the experimental proofs bearing on this point leave soine doubt as to a true demonstration, because a dilatation from the heating effect of the very strong currents used with metallic bodies may interfere, and are considered, for example, to explain the experiments of Furbes and Gore. ${ }^{x}$ But in my case, with a substance which has a very small coefficient of dilatation, I think the vibratory motion may be considered as an electrodynamic effect. As a supporting demonstration, I suspended with insulated metallic wires near another, three horizontal pieces of carbon $(3 \mathrm{~cm}$. long) in such a way that they could move freely away, and the two outer ones were connected with a battery of twenty Grove cells; innmediately on closing the circuit a repulsion ensued between them and an oscillating motion set in, whilst bright sparks appeared between the contacts.

This experiment may throw some light on a recent controversy which has arisen between Mr. Varley and Prof. Hughes. ${ }^{2}$ The latter insists on a change in contact resulting from alternating varying forms of the wolecules or their spheres of action, in accordance with the sonorous vibrations. Mr. Varley points out a quite distinct cause. By using a contact-breaker moved with the hand he discovered, on applying a microscope with a $35^{\circ}$ times magnifying power when the circuit was closed or opened, a grey cloud issuing between the nearest carbon-points. This seems to prove that little particles of carbon are loosened by an effect of trituration on the contact-surface, the cohesion being lessened by the heating effect of the current. This cloud of microscopic dust serves as a vehicle to the current (when the carbon piece is vibrating), and its resistance of course is easily modified by the impinging sound-vibrations. Norw my experiment, though with a strong current, supports this fact, and shows that the vertical carbon is actually vibrating under its influence, and may prepare the above-mentioned condition, or at least render it very ready to change its contact in accordance with sound-waves acting on it with more or less force.

Perhaps it will be observed that a microphone acts very well in transmitting sound when even the weak current from a couple of Leclanché cells is used, but then, also, we may admit a propensity (through the influence of this current) of the vertical carbon rod to get into a vibratory condition, which the sonorous vibrations will easily actuate according to their own period, if really it is not already vibrating at microscopical distances.

Prof. Hughes alludes to an experiment which, as be thinks, gives an evident support to his theory. In a sealed glass tube are inclosed five loose pieces of carbon with terminals to admit a current. He remarks that, properly pressed mere mechanical shaking produces no variation of the current except that due to a constantly increasing resislance caused by abrasion of the carbon contacts, whilst under the influence of sonorous vibrations a varying current is produced, because the tube in this case is

I Forbes, Phil. Mag., t. xvii: p. 358 . Gore; ibid, t. xv. p. sig.

2 Telegraphic foum rnat, October $x$ and $15, \mathbf{i} 878$. varying its length, and the molecules undergo proportional change of form. I think this proof may be as well, and with more probability explained by the facts mentioned above. The tube contains four or five loose pieces of carbon, and besides these some air, which, as it is in a closed space, will press from all sides on the carbon parcels when it is put in vibration by sound, and therefore alter in a mechanical way their distances, the more because the surfaces in contact are rough ones. In conclusion I will observe that the audible vibration of the vertical carbon rod in the microphone certainly elucidates the facts discovered by Blyth concerning sound transmitted only with coal cinders forming a receiving and a transmitting apparatus in a galvanic circuit, and on which he insists in a recent communication to this journal (NATURE, vol. xix. p. 72).

The Hague, December 8,1878

L. BLEEKRODE

\section{Shakespeare's Colour-Names}

IN the name of scientific accuracy and fair criticism I protest against Mr. Murphy's letter in NATURE, vol. xix. p. 197. His remarks proceed on the perfectly gratuitous assumption that all eagles have blue eyes. As this is not a fact (the only live ones I have examined had both of them green eyes), I have no hesitation in asserting that when Shakespeare wrote "An eagle, madam, hath not so green, so quick, so fine an eye as Paris hath," he did so, after having seen an eagle or eagles, and that when he said green he "evidently" meant green, and not blue.

Edinburgh, January 4

A. Craig-Christie

Your correspondent, Mr. J. J. Murphy, in his letter, NATURE, vol. xix. p. I 97 , overlooks the fact that blue is quite as inappropriate as green to describe the eye of an eagle. Shakespeare would never have used either epithet; the word he made use of was doubtless keen. Green has been substituted by the mistake of some transcriber of the play working by ear, and not by eye. I only wonder the correction has not been made long ago by some commentator.

Exeter, January 4

ROBERT BREWIN

\section{The Meteor Shower of January 2}

AFTER a very heavy fall of rain, sleet, and then snow (equalling in the aggregate $I^{\circ} 47^{2} \mathrm{inch}$, on the evening and night of January $I$, the clouds partly cleared away on the ensuing morning, and during a watch of twenty minutes $(6.14$ to 6.34 A.M., January 2) in a sky fully two-thirds overcast, fourteen meteors were seen, all of them belonging to the special shower in Quadrans. This radiant was evidently very active at the time $I$ saw it, and in a cloudless sky, must have supplied meteors at the rate of more than one per minute (for one observer). The paths were stiort and quick without streaks or trains. Radiant point at $230^{\circ}+51^{\circ}$, but not very exactly found owing to the clouds and haze through which several of the meteors were indistinctly seen. Three or four were as bright as Ist mag. stars. W, F. DENNING

Ashleydown, Bristol, January 2

\section{OUR ASTRONOMICAL COLUMN}

MISSING NEBULA.-In Mr. Ellery's Report, to which reference was made last week, it is stated that "two nebulæ, $H_{4223}$ and $H_{156 r}$, widely separated from each other, and described by Herschel as prominent objects, cannot now be found, although careful search has been made for them." The first of these nebulæ is near the cluster Dunlop 4I 3 : in the "General Catalogue" it is called "a remarkable object," but being very large and faint, it might, perhaps, be suspected that its invisibility in the Melbourne reflector is owing to the same cause that has led to the Pleiades-nebula, and other similar diffused objects (as. G. C. I 32,4570 , 5051) being overlooked in very large telescopes though obvious in much smaller ones. But in the case of H $156 \%$ no such supposition is admissible. It was observed by Sir John Herschel on five occasions, in sweeps made between December, I834, and February, 1836; when best seen it was termed pretty bright, from $25^{\prime \prime}$ to $35^{\prime \prime}$ in diameter, gradually brighter towards the centre, and situate to the south of, though very near to, three stars of the eleventh 
magnitude. Taking a mean of the five observations of position, and reducing to 1880 , its R.A. is $7 \mathrm{~h} .35 \mathrm{~m}$. 8 os. and N.P.D., I $59^{\circ} 0^{\prime} 46^{\prime \prime}$.

We do not hear of recent observation of the nebula situated near $\zeta$ Tauri, which was discovered by Chacornac, and which was sufficiently bright from 1855 , October I 9 , to I856, January 27 , to "cause surprise that it had not been inserted by Mr. Hind upon his ecliptic charts," though it was not perceived on the meridian even with a refractor of 25 centimetres from 1853 , December 3 , to 1854 , December 17. In I $855-56$ the nebula was projected upon a star of the eleventh magnitude, the position of which for 1880 is in R.A. 5 h. 30m. 16.0s, and N.P.D. $68^{\circ} 51^{\prime} 29^{\prime \prime}$. Chacornac says: "Elle offrait une forme presque rectangulaire, dont le plus grand côte soutendait un angle de trois minutes et demie, et le plus petit un arc de deux minutes et demie." D'Arrest, 1863 , September 82 , could not perceive any nebulosity about the star, nor, 1165 , January 25 , "colo valde eximio." He notes that the star is double, estimated distance $40^{\prime \prime}$. It precedes $\zeta$ Tauri $12^{\circ} 5$ s., and is north of it $4^{\prime} 28^{\prime \prime}$.

Some years since the approximate places of three nebulosities remarked with the comet-seeker at Cambridge, U.S., by Mr. G. P. Bond, but subsequently missed, were published. One seen 1850 , February 27 , in R.A. oh. $47 \mathrm{~m} .415 . \pm 1 \mathrm{~m} . ;$ N.P.D. $26^{\circ} 36^{\prime} \pm 19^{\prime}$, could not be found 1863 , September 9. A faint and rather large nebula, seen 1850 , December 30 , was not to be found, 1863 , August 17 ; R.A. 14h. $37 \mathrm{~m}$. $\pm 3 \mathrm{~m}$., N.P.D. $67^{\circ} \mathrm{o}^{\prime} \pm 30^{\prime}$, and a third nebulosity resembling a comet, observed 1850 , November 7 , in R.A. 23 h. 50 m. 46 s., N.P.D. $123^{\circ} 24^{\prime}$, requires verification; the place is for 1850 .

\section{GEOGRAPHICAL NOTES}

UNDER the direction of the United States Hydrographic Office, Lieut.-Commander F. M. Green, U.S.N., and the officers under his command, have during the last four years been engaged in determining exactly secondary meridians of longitude by means of the submarine telegraph cables in the West Indies and South America. The result of the West India work in 1874,1875 , and 1876 was the determining the latitude and longitude of a large number of points in the West Indies with the utmost possible exactness; and during the past year this work, of the greatest value to geographical and geodetical science, has been continued by making a chain of telegraphic measurements from the Royal Observatory at Lisbon, by way of Madeira, St. Vincent, Pernambuco, Bahia, Rio de Janeiro, and Monte-Video to Buenos Ayres, there connecting with the observatories of Cordova and Santiago. This chain is perfect, with the exception of one link on the coast of Brazil, where the cable was broken, necessitating the procuring of new cable from England; but its completion will be effected before the computation of the observations already made can be finished. The method used for determining the latitude was in all cases that of the zenith telescope, brought to great perfection by the United States Engineers and the Coast Survey; that for differences of longitude, the comparison by repeated telegraphic signals of two chronometers at the ends of the telegraph cable, determining their errors both before and after the comparison by numerous transits of stars over the meridian. All that is needed to make the work of the last year perfect and complete is the telegraphic determination of the differences of longitude between the Greenwich and Lisbon observatories, and the completion of the imperfect link on the Brazilian coast, both of which will be done during the coming year. Until the observations have been carefully discussed, the results as compared with former determinations cannot be known exactly, but a preliminary computation indicates that the longitude of the coast of
Brazil is laid down about three or three and a half miles too far west, this westerly error being indicated in a less degree in the longitudes of Madeira and St. Vincent.

LORD AUGUSTUS LOFTUS has recently forwarded to the Foreign Office, from St. Petersburg, a translation of a Russian letter from Cabul, descriptive of the journey of General Stoletoff's mission from Samarcand, which supplies some notes of interest respecting the country traversed. The road selected for reaching the Oxus was through Huzar, Shirabad, and Chushkogosar, which was traversed in five days. On this route the mission passed through the famous defile known in ancient times under the name of the "Iron Gates," and now called Burghasse Khana. The mission crossed the Oxus in very primitive boats, and marching by night, passed over a sandy arid steppe, and next morning reached Kurshiak settlement, situated in a cultivated country. They made three stages before reaching Mizar and Sheriff, where great crowds thronged the streets, and gazed with curiosity on the people from the distant north. After leaving Tashurgan, the party reached the spurs of the Hindu Kush, and journeyed to Cabul during twenty days. Ascending at first in gentle slopes, the Hindu Kush gradually rises higher and higher, forming, amidst its frequent passes, terraces of increasing height. After traversing a series of such terraces, the mission reached the elevated Bamian Valley (8,500 feet), near which are the Kdlu and Great Tran Passes (13,000 feet). Passing the famous Bamian idols, chiselled on the face of the rock, they emerged from the last-named pass, and then descended from the Ugly Pass into the Cabul Darya Valley, at a place three days' journey from the capital of Afghanistan.

THE French papers published last week news from the Gaboon settlements stating that the Ogowe exploring. mission had arrived in Libreville, the head city of the colony. A telegram read at the last sitting of the Paris. Geographical Society announced that M. Brazza, the chief of the mission, had arrived in Lisbon with some of his subordinates, on his way to Paris. It was expected he would arrive in time for the meeting of the Society on Tuesday. The exploration of the mission has lasted three years, and many highly important results are said to have been obtained.

AT the last sitting of the Paris Geographical Society M. de Lesseps read a telegram received from Capt. Roudaire, stating that he had found nothing but compressed sand when boring to a depth of 30 metres in the Gabes Isthmus, so that no real difficulty prevented the opening of it for the intended Saharan Sea.

ON the authority of Mr. Oscar Dickson, it is stated. that the Nordenskjold expedition is wintering forty miles. north of Cape East in Behring Straits. This news has. been given to American whalers by a party of trustworthy natives, and a number of whalers are said to be wintering with the Vega.

THE just issued October Bulletin of the Paris Geographical Society contains a long paper by $M$. Léon Rousset, giving the results of a journey in the upper basin of the Yellow River and the region of the loess which. overspreads so large an area of China, and of which Richthofen makes so much in his great work on China. M. Dutreuil de Rhins contributes a very useful account of Annam and the province of Hué ; M. H. Harrisse discusses the question of the burial-place of Columbus, and: M. d'Abbadie concludes his useful description of the instruments to be used in travel.

A LiTTLE work on Afghanistan has just been published by Dr. Josef Chavanne, the author of the excellent work on the Sahara. It is written with special reference to the 